\title{
Agroforestry: A tool for climate change adaptation, mitigation and enhanced food security
}

\author{
Anubha Das* \\ * Department of Zoology, Zakir Husain Delhi College (M), University of Delhi, India \\ DOI: 10.29322/IJSRP.12.01.2022.p12131 \\ http://dx.doi.org/10.29322/IJSRP.12.01.2022.p12131
}

\begin{abstract}
An ever increasing human population exerts a tremendous pressure on agriculture to increase production, to meet the rising food demand. With increasingly deteriorating arable land quality, decreasing soil fertility, increasing soil erosion and dwindling resources, the challenge is further intensified by climate change. Its ironical only that agriculture, one of the major contributing sectors, towards global warming is also the most vulnerable to climate change. The problem exacerbates, especially for the subsistence agriculture, as small landholding farmers already struggling a plethora of sustainability issues emerging from climate change, lack resources to adapt to or combat climate change. Agroforestry has the potential to help, not only combat global warming but also small landholding farmers to gain economically and adapt to climate change. The present paper is an attempt to highlight the role of agroforestry as a tool for climate change adaptation, mitigation and enhanced food security and reaffirm the necessity of including agroforestry as part of the solution to combat climate change and global food insecurity.
\end{abstract}

Index Terms- agriculture, agroforestry, climate change adaptation, climate change mitigation, food security

\section{INTRODUCTION}

$\mathrm{C}$ limate and agriculture are inseparable entities. Consequently, climate change, the defining crisis of Anthropocene is exacerbating food insecurity $(9,24)$, a major global societal challenge today, as agriculture, experiencing immense pressure to intensify food production owing to our ever-mounting human population has been severely impacted by climate change [1,5,24]. Every dimension of agricultural production is prone to climate change influence in one way or other, altering both quantity and quality of yield.

As per United Nations report the world population is expected to touch 9.8 billion mark in 2050 [30] and to sustain that mammoth population global food production demands 70\% enhancement (7). The production can be increased by expanding arable land and it is expected to increase by 200 million hectares, in 2050 [7]. This expansion may come at a huge ecological cost as more forest land would be cleared, devastating the natural ecosystems and releasing the carbon sequestered in soil and trees back into atmosphere. Interestingly, the expansion of arable land will not translate into increase in per capita arable land. Projections indicate that worldwide per capita arable land will be reduced to 0.19 hectares in 2050 as compared to 0.42 hectares in 1960 . The effect will be more pronounced in developing countries with per capita arable land expected to be reduced to 0.14 hectares from 0.33 hectares [7]. Whether we will be able to increase food production to match the food demand in 2050, remains debatable as the Sustainable Development Goals (SDGs) Target 2.1 of achieving zero hunger by 2030 seems a herculean task under present scenario where 746 million people experienced severe food insecurity in 2019 [11]. With increasingly dwindling resources, additional demand for food production, reduced land to grow and the changing climate, agriculture needs to fight at multiple fronts, simultaneously.

\section{Climate change and food insecurity:}

Agri-food systems alone contribute one-third of total anthropogenic greenhouse gases (GHG) emissions [4] at the same time the sector is facing the major brunt of climate change and associated events. An unprecedented array of old and emerging, interconnected challenges is influencing global agricultural production [10] and exacerbating the food insecurity of an already hungry world. The intangible dependence of agriculture on environment and climate conditions make it extremely vulnerable to climate change [5] and other events rooted in the same, amplifying the food-security challenge (Fig.1). The problem intensifies in case of developing countries where livelihood depends to a great extent on agricultural activities. Climate change thus emerges as a key driver behind food insecurity and mounting global hunger [12]. 


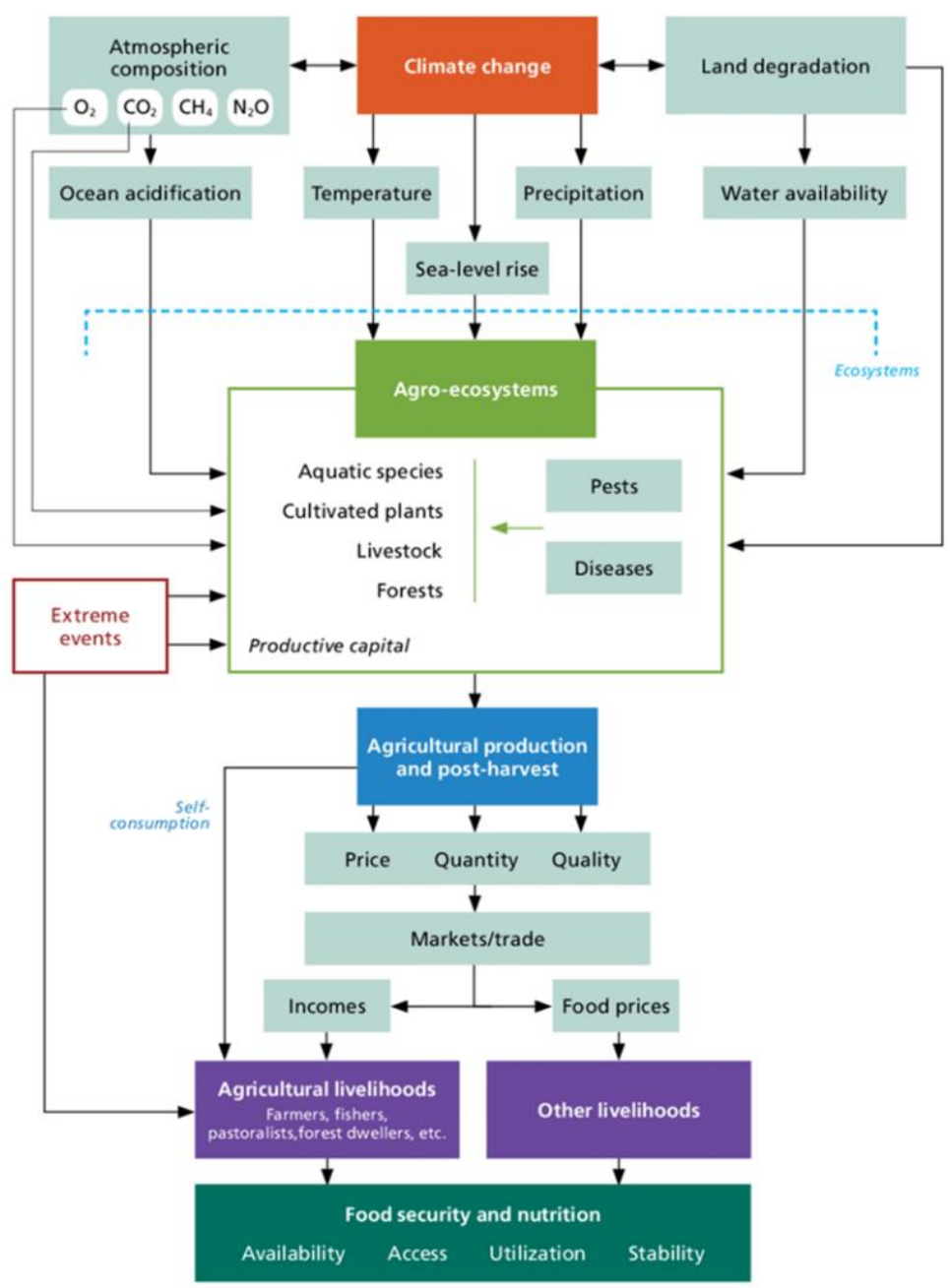

Fig 1: Cascading effects of climate change impacts on food security and nutrition Source credit: FAO, 2015

\section{Agroforestry: climate change adaptation, mitigation and increased food-security:}

Climate change despite being a global issue, its impacts are heterogeneous and experienced locally. Therefore, a two-pronged approach comprising adaptation and mitigation both, is required to address this imminent global emergency. Intergovernmental Panel for Climate Change (IPCC) has defined adaptation as "adjustment in natural or human systems in response to actual or expected climatic stimuli or their effects, which moderates harm or exploits beneficial opportunities" [14]. It works at the local level and its effect can be short lived. It comprises reducing the negative impacts /vulnerability while gaining benefits from potential opportunities. Mitigation, works at global scale and encompasses long term measures to reduce the sources and enhance the sinks of GHG emissions. It becomes crucial to harness the synergies between climate change adaptation and mitigation strategies and both are imperative for agriculture sector. Agroforestry offers both climate change adaptation and mitigation.

Agroforestry has been part of agriculture for millennia and practiced in different parts of the globe by farmers. Despite being a traditional farming system, offering a plethora of agricultural, environmental and socio-economic benefits [27] it remained alienated in many parts of the world for long. 


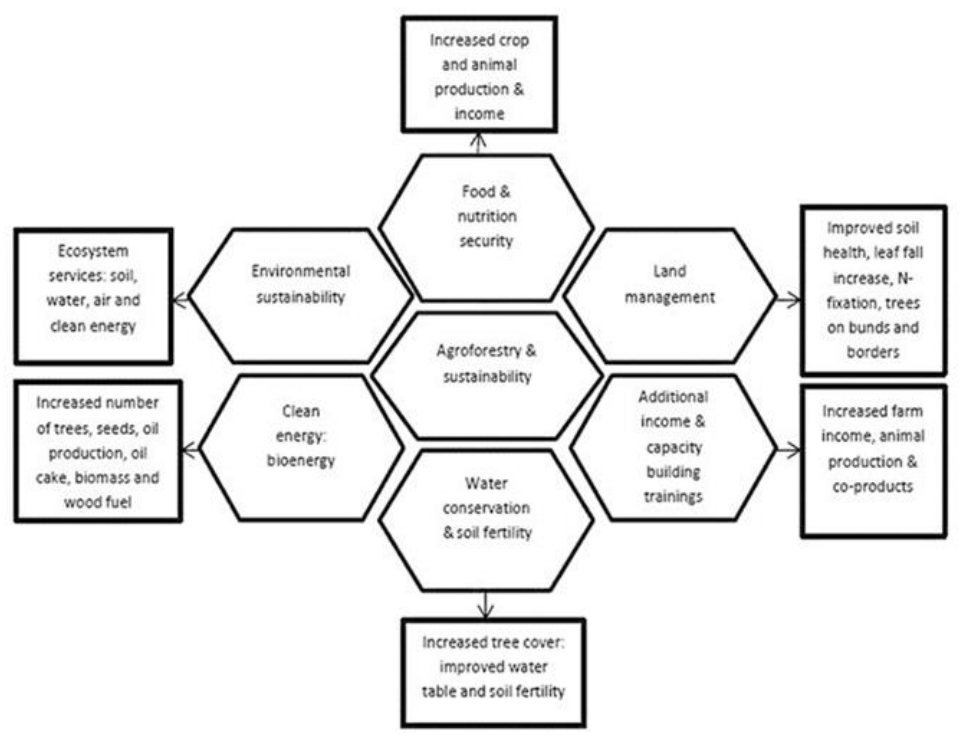

Fig:2 Multiple benefits from Agroforestry system Source credit: Adapted from Sharma et.al. 2016

The practice is now emerging as a lynchpin of climate smart agriculture (CSA), addressing both climate change and food insecurity. This dynamic, integrated farming approach based on ecological principles grows tress/shrubs along with crops, to create structurally as well as functionally complex agro-ecosystems and can contribute to climate change adaption, mitigation [6,29] and better resilience in agro-ecosystems and farmer [2,21,22], especially smallholder farmers $[6,16]$, to climate variability. The practice, exhibiting an interface of agriculture and forest, integrates trees along with main crops to mimic the natural ecosystems for increased productivity [16], soil health and fertility, biodiversity, prevent soil erosion, various ecosystem services [17,18,32,33] and increased income (Fig 2). The improved land use efficiency yields increased agricultural production and economic returns $[3,16]$ from same agricultural land, translates into enhanced food security. To meet the climate goals many developing countries (non-Annex I) across the globe are practicing agroforestry as part of the strategy, already or planning to use it, realizing its potential for climate change mitigation and/or adaptation (Fig 3). It was featured as the land- use practice with highest carbon sequestration potential, of all the land uses analyzed in the Land-Use, Land-Use Change and Forestry report of the International Panel on Climate Change [13]. Carbon (C) sequestration is a key component of climate change mitigation interventions and can contribute enormously in reducing atmospheric $\mathrm{CO} 2$ concentration. Agroforestry can substantially increase the terrestrial carbon sequestration [25], mitigating climate change and enhancing soil carbon that bears a direct impact on soil fertility [17,31].

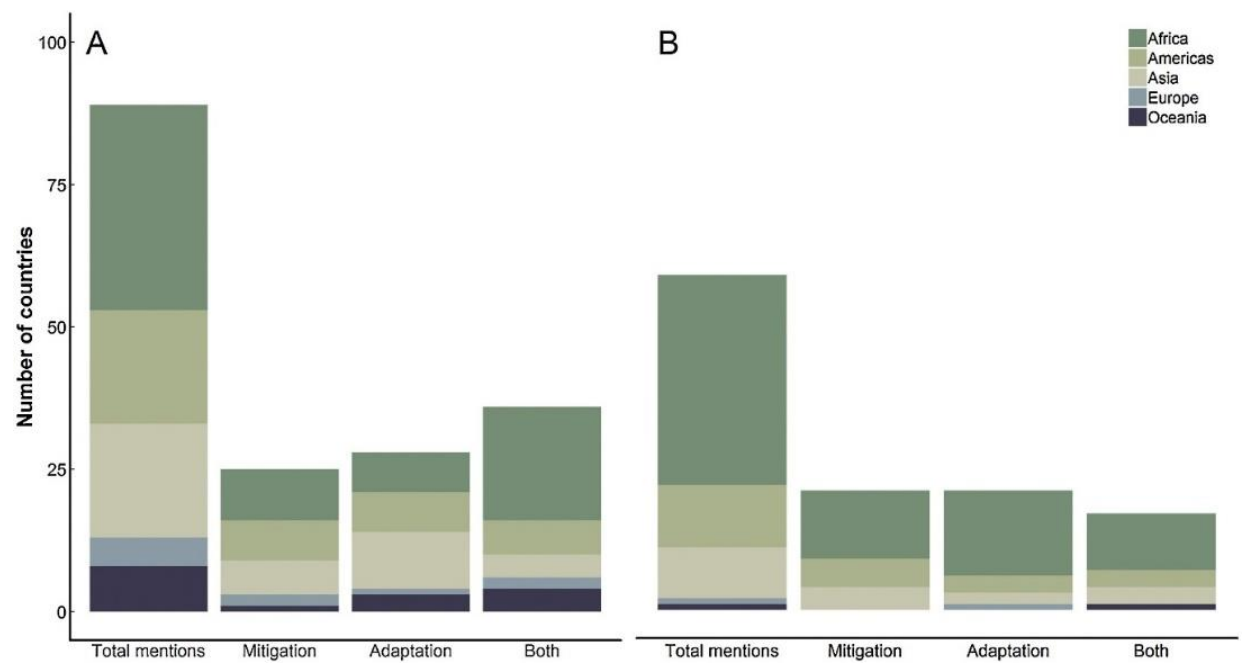

Fig 3. Agroforestry mentioned in National communications (NCs) of non-Annex I countries ( $\mathrm{N}=147$ ) (A) and Nationally Determined Contributions (NDCs) of non-Annex I countries ( $=148)$ (B). Here "Total mentions" refers to all documents that mentioned agroforestry irrespective of whether it appeared as a solution for mitigation or adaptation. "Mitigation" are all documents that refer agroforestry as solution for mitigation while "adaptation" are the documents that used it as solutions for adaptation. "documents that mentioned Agroforestry as a solution for both "adaptation and mitigation". Source credit: Rosenstock et.al, 2019 
Other than sequestrating carbon above and below ground, agroforestry serves as a sink for greenhouse gases (GHG) reducing GHG emissions, when managed scientifically, taking into account the existing edaphic and climatic conditions. Biomass, used as a fuel source in rural areas, can further contribute by replacing fossil fuel that generates emissions significantly higher than those from biomass, a renewable energy source.

\section{Challenges for Agroforestry Systems:}

There are plethora of constraints hindering adoption of agroforestry. Monoculture farming exhibits dominance over mixed farming owing to high yield and profitability. The gain though short term is lucrative and a major hindrance for adoption of agroforestry. Lack of training and awareness about role of agroforestry in land quality improvement [19] and climate change mitigation and adaption also pose barriers in scaling up the practice. Other constraints include lack of or poor access to resources like land, money, quality germplasm, inputs from experts $[15,19,23]$ and markets. Various restrictive legislative regulations and lack of agroforestry encouraging policies $[19,20]$ also create hurdle in its adoption. Agroforestry demands proper planning and selection of appropriate plants and tree species to be intercropped, based on agro- ecological factors that are highly variable geographically, requiring experts' help at least in the initial phase of adoption. In contrast to monoculture farming, agroforestry requires time to bear its fruits. The long gap between planting trees and harvesting the products, is another deterrent and goes in favour of monocultures offering quick returns [20]. Lack of knowledge or access to market and value chains is another detrimental factor, hampering agroforestry adoption by small scale farmers [20]. Despite the huge market for organic products ranging from fruits, cosmetics to medicines, in the absence of organized and well- monitored marketing systems, farmers do not get their due share and profit remains low. Direct linkages between farming community and various institutions utilizing the tree products needs to be established to promote agroforestry.

\section{CONCLUSION}

Agroforestry has got immense potential as a tool to redesign agricultural practices and land use pattern in the present scenario to confront climate change, both as an adaptation as well mitigation strategy. The practice offers multitude of environmental and ecological advantages and economic gain, a major incentive, translating into intensified food-production leading to increased income, food-security and empowerment of small-scale farmers practicing it. It has been practiced in many parts of the globe and results are very promising yet its potential to transform into a strategy for climate change mitigation and adaptation and increasing food security remains underused. There is a need for increased awareness and capacity- building through training to promote agroforestry, calling for greater support from agricultural experts and institutions. A major constraint preventing socio-economic benefits of agroforestry flowing immediately down to participating communities can be resolved by developing market and direct linkages between such communities and domestic, regional and national markets. Combining traditional knowledge and wisdom of farmers with scientific knowledge of agriculturists is vital for designing appropriate agroforestry models, based on geographical, ecological and environmental constraints and advantages. Agroforestry-unfavourable legislation, regulations and policies need to be revisited to address the issues hindering the adoption of agroforestry by small-scale farmers. It is heartening to witness the emergence of agroforestry in global climate change discourses as an adaptation strategy as well as contributing to food-security but requires a consistent effort to overcome the various challenges hampering its adoptability. A conclusion section is not required. Although a conclusion may review the main points of the paper, do not replicate the abstract as the conclusion. A conclusion might elaborate on the importance of the work or suggest applications and extensions.

\section{REFERENCES}

[1] Ajilogba C.F., Walker S. 2021. Climate Change Adaptation: Implications for Food Security and Nutrition. In African Handbook of Climate Change Adaptation, Leal Filho W., Oguge N., Ayal D., Adeleke L., da Silva I. (eds). Springer, Cham. https://doi.org/10.1007/978-3-030-45106-6_142

[2] Badege, B., Neufeldt, H., Mowo, J., Abdelkadir, A., Muriuki, J., Dalle, G., Assefa,T., Guillozet, K., Kassa, H., Dawson, I.K., Luedeling,E., and Mbow, C., 2013. Farmers' Strategies for Adapting to and Mitigating Climate Variability and Change through Agroforestry in Ethiopia and Kenya, edited by Caryn M. Davis, Bryan Bernart, and Aleksandra Dmitriev. Forestry Communications Group, Oregon State University, Corvallis, Oregon. 96p.

[3] Boubié Vincent Bado, Anthony Whitbread, Maman Laminou Sanoussi Manzo, 2021. Improving agricultural productivity using agroforestry systems: Performance of millet, cowpea, and ziziphus-based cropping systems in West Africa Sahel. Agriculture, Ecosystems \& environment, 305,107175, ISSN 0167-8809, https://doi.org/10.1016/j.agee.2020.107175.

[4] Crippa, M., Solazzo, E., Guizzardi, D., Monforti-Ferrario, F., Tubiello, F.N., and Leipet, A. 2021. Food systems are responsible for a third of global anthropogenic GHG emissions. Nature Food 2, 198-209. https://doi.org/10.1038/s43016-021-00225-9

[5] Das, A. 2021. Climate Change and Myriad Ways Its Impacting the World. International Journal of Scientific and Research Publications, 11 (12): $26-30$

[6] Edmundo Barrios, Vivian Valencia, Mattias Jonsson, Alain Brauman, Kurniatun Hairiah, Peter E. Mortimer \& Satoru Okubo. 2018. Contribution of trees to the conservation of biodiversity and ecosystem services in agricultural landscapes, International Journal of Biodiversity Science, Ecosystem Services \& Management, 14:1, 1-16, DOI: 10.1080/21513732.2017.1399167

[7] FAO. 2011. Looking Ahead in World Food and Agriculture: Perspectives to 2050.Rome, Italy. 
[8] FAO. 2013. Advancing Agroforestry on the Policy Agenda: A guide for decision-makers, by G. Buttoud, in collaboration with O. Ajayi, G. Detlefsen, F. Place \& E. Torquebiau. Agroforestry Working Paper no. 1. Food and Agriculture Organization of the United Nations. FAO, Rome. 37 pp.

[9] FAO. 2015. Climate change and food security: risks and responses. Rome, Italy.

[10] FAO, IFAD, UNICEF, WFP and WHO. 2021. The State of Food Security and Nutrition in the World 2021.Transforming food systems for food security, improved nutrition and affordable healthy diets for all. Rome, FAO. https://doi.org/10.4060/cb4474en

[11] FAO. 2021. The impact of disasters and crises on agriculture and food security: 2021. Rome. https://doi.org/10.4060/cb3673en

[12] Holleman, C., Rembold, F., Crespo, O. \& Conti, V. 2020. The impact of climate variability and extremes on agriculture and food security - An analysis of the evidence and case studies. Background paper for The State of Food Security and Nutrition in the World 2018. FAO Agricultural Development Economics Technical Study No. 4. Rome, FAO

[13] IPCC, 2000 -Watson, R.T., Noble, I.R., Bolin, B., N. H. Ravindranath, N. H., Verardo, D.J., and Dokken, D.J. (Eds.) Cambridge University Press, UK. 375p.

[14] IPCC, 2001: Climate Change 2001: Synthesis Report. A Contribution of Working Groups I, II, and III to the Third Assessment Report of the Intergovernmental Panel on Climate Change, Watson, R.T. and the Core Writing Team (eds.)]. Cambridge University Press, Cambridge, United Kingdom, and New York, NY, USA, 398 pp.

[15] Kuyah, S., Whitney, C.W., Jonsson, M., Sileshi, G.W., Öborn, I., Muthuri C.W., and Luedeling, E. 2019. Agroforestry delivers a win-win solution for ecosystem services in sub-Saharan Africa. A meta-analysis. Agron. Sustain. Dev. 39, 47. https://doi.org/10.1007/s13593-019-0589-8

[16] L.C. Gomes, F.J.J.A. Bianchi, I.M. Cardoso, R.B.A. Fernandes, E.I. Fernandes Filho, R.P.O. Schulte, 2020. Agroforestry systems can mitigate the impacts of climate change on coffee production: A spatially explicit assessment in Brazil. Agriculture, Ecosystems \& Environment,294, 106858, ISSN 0167-8809, https://doi.org/10.1016/j.agee.2020.106858

[17] Mario Torralba, Nora Fagerholm, Paul J. Burgess, Gerardo Moreno, Tobias Plieninger 2016. Do European agroforestry systems enhance biodiversity and ecosystem services? A meta-analysis. Agriculture, Ecosystems \& Environment, 230, 150-161. ISSN 0167-8809, https://doi.org/10.1016/j.agee.2016.06.002

[18] Mary N. Muchane, Gudeta W. Sileshi, Sofia Gripenberg, Mattias Jonsson, Lorena Pumariño, Edmundo Barrios. 2020. Agroforestry boosts soil health in the humid and sub-humid tropics: A meta-analysis, Agriculture, Ecosystems \& Environment, 295, 106899, ISSN 0167-8809, https://doi.org/10.1016/j.agee.2020.106899.

[19] Mbatha Masibo, M., Hitimana, J., Sitienei Yegon, A., \& Odongo Owino, Y. 2018. Challenges Affecting the Adoption of Agroforestry Practices around Chepalungu Forest in Bomet County, Kenya. Asian Journal of Advanced Research and Reports, 2(1), 1-10. https://doi.org/10.9734/ajarr/2018/v2i116184

[20] Mwase, W., Sefasi, A., Njoloma, J., Nyoka, B., \& Manduwa, D., Nyaika, J. 2015. Factors Affecting Adoption of Agroforestry and Evergreen Agriculture in Southern Africa. Environment and Natural Resources Research. 5. 10.5539/enrr.v5n2p148.

[21] Nair, P.K.R \& Garrity, D. 2012. Agroforestry - The Future of Global Land Use. Springer, Dordrecht, 542P.

[22] Nyong, A.P., Ngankam, T.M. \& Felicite, T.L. 2020. Enhancement of resilience to climate variability and change through agroforestry practices in smallholder farming systems in Cameroon. Agroforest Syst 94, 687-705. https://doi.org/10.1007/s10457-019-00435-y

[23] Pilote Kiyani, Jewel Andoh, Yohan Lee \& Don Koo Lee. 2017 Benefits and challenges of agroforestry adoption: a case of Musebeya sector, Nyamagabe District in southern province of Rwanda. Forest Science and Technology, 13:4, 174-180, DOI: 10.1080/21580103.2017.1392367

[24] Rahman, A., Mojid, M.A. and Banu, S. 2018. Climate change impact assessment on three major crops in the north-central region of Bangladesh using DSSAT. Int. J. Agril. Biol. Engi. 11(4): 135-143. https://doi.org/10.25165/j.ijabe.20181103.3331

[25] Rico Hübner, Anna Kühnel, Jie Lu, Hannes Dettmann, Weiqi Wang, Martin Wiesmeier. 2021. Soil carbon sequestration by agroforestry systems in China: A meta-analysis, Agriculture, Ecosystems \& Environment., 315,107437, ISSN 0167-8809, https://doi.org/10.1016/j.agee.2021.107437.

[26] Rosenstock TS, Wilkes A, Jallo C, Namoi N, Bulusu M, Suber M, Mboi D, Mulia R, Simelton E, Richards M, Gurwick N, Wollenberg E. 2019. Making trees count: Measurement and reporting of agroforestry in UNFCCC national communications of non-Annex I countries. Agriculture, Ecosystems \& Environment 284:106569.

[27] Sharma, N., Bohra, B., Pragya, N., Ciannella, R., Dobie, P., and Lehmann, S. 2016. Bioenergy from agroforestry can lead to improved food security, climate change, soil quality, and rural development. Food and Energy Security., 5 (3): 165-183. 10.1002/fes3.87. DOI:10.1002/fes3.87

[28] Schleussner, C.-F., Lissner, T. K., Fischer, E. M., Wohland, J., Perrette, M., Golly, A., Rogelj, J., Childers, K., Schewe, J., Frieler, K., Mengel, M., Hare, W., and Schaeffer, M. 2016. Differential climate impacts for policy-relevant limits to global warming: the case of $1.5{ }^{\circ} \mathrm{C}$ and $2{ }^{\circ} \mathrm{C}$, Earth Syst. Dynam., $7: 327-351$, doi:10.5194/esd-7-327-2016

[29] Schoreneberger, M., Bendrub, G., Gooijer, H., Soolanayakanahal, R., Sauer, T., Brandle, J., Zhan, X. and Cuer, D. 2012. Branching out: agroforestry as a climate change mitigation and adaptation for agriculture. J. Soil Water Conserv., 67(5): 128-136. https://doi.org/10.2489/jswc.67.5.128A

[30] United Nations. 2017. The Impact of Population Momentum on Future Population Growth. Population Facts. No. $2017 / 4$.

[31] Ussiri D.A., Lal R. 2017. Introduction to Terrestrial Carbon Sequestration. In: Carbon Sequestration for Climate Change Mitigation and Adaptation. Springer, Cham. 327-341p. https://doi.org/10.1007/978-3-319-53845-7_9

[32] Verchot, L.V., Van Noordwijk, M., Kandji, S., Tomich, T., Ong, C., Albrecht, A., Mackensen, J., Bantilan, C., Anupama „K.V. and Palm,C. 2007. Climate change: linking adaptation and mitigation through agroforestry. Mitig Adapt Strat Glob Change 12, 901-918. https://doi.org/10.1007/s11027-007-9105-6

[33] Zhang, W., Wang, B.J., Gan, Y.W. et al. 2017. Competitive interaction in a jujube tree/wheat agroforestry system in northwest China's Xinjiang Province. Agroforest Syst 91, 881-893. https://doi.org/10.1007/s10457-016-9962-7

\section{AUTHORS}

First Author - Anubha Das, Ph.D., Zakir Husain Delhi College (M), Department of Zoology, University of Delhi, India

Correspondence Author - Anubha Das, yanubha@gmail.com, 9891874260 